\author{
I.В. Лагута ${ }^{1}$, О.М. Ставинська ${ }^{1}$, П.О. Кузема ${ }^{1}$, \\ Р.В. Іванніков ${ }^{2}$, В.М. Аніщенко ${ }^{3}$, О.П. Ліннік ${ }^{1}$ \\ ${ }^{1}$ Інститут хімії поверхні ім. О.О. Чуйка НАН України, Київ \\ ${ }^{2}$ Національний ботанічний сад ім. М.М. Гришка НАН України, Київ \\ ${ }^{3}$ Інститут фізико-органічної хімії і вуглехімії ім. Л.М. Литвиненка НАН України, Київ \\ E-mail: icvmtt34@gmail.com
}

\title{
Антиоксидантні властивості рослинних екстрактів - стабілізаторів біодизелю
}

Представлено иленом-кореспондентом НАН України В.В. Туровим

3 використанням двох різних процедур екстракції одержано вісім етанольних екстрактів із листя рослин Magnolia $\times$ soulangeana Soul.-Bod., Magnolia kobus mа двох зразків Camellia jаропіса L. За допомогою високоефективної рідинної хроматографії, методу Фоліна-Чокальтеу і DPPH тесту вивчено склад та антиоксидантні властивості одержаних екстрактів. Показано, що основними складовими екстрактів магнолій $\epsilon$ глікозиди кверцетину та похідні оксикоричних кислот, тоді як у екстрактах камелій переважають катехіни і похідні оксибензойних кислот. Склад екстрактів залежить не тільки від виду рослини, а й від способу екстрагування; загалом, екстракти, одержані при температурі $60^{\circ} \mathrm{C}$ та під дією ультразвуку, мають більший вміст поліфенолів, ніж екстракти, отримані кип'ятінням рослинного матеріалу у 70 \% -му етанолі при $\sim 85^{\circ} \mathrm{C}$; загальна кількість фенольних сполук у екстрактах змінювалась у діапазоні 50-150 мг/л. Виявлено, що, попри значну різницю у вмісті фенолів, всі екстракти мають дуже високу антиоксидантну активність як у тесті Фоліна-Чокальтеу, так і в реакиї з DРPН радикалами. Показано, що екстракти мають загальний фенольний індекс 1,5-7,5, а протягом 30 хв реакції сім з восьми екстрактів інгібують понад $50 \%$ радикалів DРPН навіть після розведення у 10 разів. Екстракт камелії з найвищими антиоксидантними властивостями було протестовано як добавку до біодизелю, що має запобігти його окисненню під час зберігання. Стабільність біодизелю, одержаного з Caтеlina sativa (L.) Crantz, досліджували за прискореною прочедурою при $43^{\circ} \mathrm{C}$ протягом чотирвох тижнів, критерієм окиснення біопалива слугувало його кислотне число. Попередні результати показали, що екстракт камелї може бути ефективним антиоксидантним агентом - запобіжником окиснення біодизелю.

Ключові слова: рослинні екстракти, фенольні сполуки, антиоксидантні властивості, стабільність біодизелю.

Одним із перспективних напрямів досліджень у межах нової ініціативи Свропейського Союзу “Свропейський зелений курс” є пошук відновлюваної рослинної сировини, яку можна використовувати для одержання біоактивних речовин і для виробництва біологічного

Ци т у в ан н я: Лагута І.В., Ставинська О.М., Кузема П.О., Іванніков Р.В., Аніщенко В.М., Ліннік О.П. Антиоксидантні властивості рослинних екстрактів - стабілізаторів біодизелю. Допов. Нац. акад. наук Укр. 2021. № 2. C. 91-99. https://doi.org/10.15407/dopovidi2021.02.091 
пального. Особливу цінність мають рослини та біовідходи, які містять поліфенольні сполуки, що виявляють антиоксидантні/відновлювальні властивості і можуть бути застосовані в медицині, харчовій промисловості, “зеленому” синтезі наночастинок металів та як стабілізатори біодизелю для запобігання його деградації під час зберігання [1-3].

Підвищити стійкість біодизелю до окиснювальної деградації можна шляхом додавання антиоксидантів [3]. У виробництві біодизелю не існує єдиного інгібітора, який підходить для всіх видів біопалива, тому розширення асортименту антиоксидантів і пошук ефективних природних відновників є актуальним. Джерелом природних антиоксидантів можуть бути вегетативні органи рослин, насамперед листя.

Раніше ми досліджували антиоксидантні властивості широкого кола рослин різних видів, що можуть бути джерелом ефективних антиоксидантів [4]. Серед рослин, які можна вирощувати в кліматичних умовах України, високим вмістом поліфенолів відзначаються, зокрема, магнолії [4]. У південних областях України та в умовах оранжерей також можливо вирощувати камелії, які, як відомо, містять велику кількість антиоксидантів; беручи до уваги зміни клімату, можна очікувати, що ці рослини згодом можуть бути розповсюджені в інших регіонах України. Відомо, що магнолії є цінним джерелом таких антиоксидантів, як флавоноли, а камелії - катехінів [5, 6]. I флавоноли, і катехіни є поліфенольними сполуками, що мають значну антиоксидантну активність та є перспективними для використання як у медичних цілях, так і для стабілізації біопалива.

Мета даного дослідження - визначення складу і антиоксидантних властивостей екстрактів магнолій та камелій і впливу способу екстракції на кількість екстрагованих біоактивних речовин. Також нами оцінено можливість використання одержаних екстрактів як стабілізаторів біодизелю для запобігання його деградації під час зберігання.

Для отримання біоактивних екстрактів використовували листя рослин Magnolia × soulangeana Soul.-Bod. (магнолія суланжа), Magnolia kobus (магнолія кобус) та два зразки листя Camellia japonica L. (камелія японська) (зразки 1 і 2 було відібрано з різних рослин). Рослинний матеріал для дослідження відбирали в Національному ботанічному саду ім. М.М. Гришка НАН України; дерева магнолій росли у природних умовах, тоді як камелії вирощували в оранжереї в умовах ex vitro. Екстракти Magnolia × soulangeana Soul.-Bod., Magnolia kobus та Camellia japonica L. отримували таким чином. Брали дві наважки подрібненого свіжого листя по 1 г. Першу наважку заливали 100 мл 70 \%-го етанолу і кип'ятили зі зворотним холодильником (температура кипіння $70 \%$-го етанолу $~ 85{ }^{\circ} \mathrm{C}$ ) протягом 2 год. Другу наважку заливали 20 мл 70 \%-го етанолу і екстрагували під дією ультразвуку при $60{ }^{\circ} \mathrm{C}$; через 30 хв екстракт зливали, а процедуру екстракції повторювали ще чотири рази. (Відповідні зразки екстрактів після назви рослини мають позначки “85 C” та “60 C+У3" відповідно.)

Аналіз та визначення класів біологічно активних речовин проводили за допомогою автоматичного чотириканального рідинного хроматографа Agilent 11003 діодно-матричним детектором і хімічною станцією на колонці Poroshell 120 EC-C18 2,1×150 мм 2,7 мкм. Хроматограми реєстрували при довжині хвиль 206, 254, 300, 350 та 450 нм. Кількість зареєстрованих у хроматограмах сполук різних класів оцінювали шляхом зіставлення площі відповідних сигналів із площею сигналів у хроматограмах реперних сполук - представників цих класів. Реперною сполукою для похідних галової кислоти, а також для фенолів і оксибензойних кислот слугувала галова кислота, для похідних елагової кислоти - елагова 
кислота, для оксикоричних кислот та їх похідних - хлорогенова кислота, для глікозидів кверцетину та кемферолу - рутин, для катехінів та галату епігалокатехіну - епікатехін та галат епігалокатехіну.

Антиоксидантні властивості рослинних екстрактів досліджували за допомогою методів Фоліна-Чокальтеу та DPPH тесту. Для визначення загального фенольного індексу [7] до 1 мл екстракту послідовно додавали 11,5 мл води, 5 мл 20 \%-го розчину карбонату натрію, 1,25 мл реактиву Фоліна-Чокальтеу і 6,25 мл води, так що сумарний об'єм розчину становив 25 мл. Розчин перемішували 30 хв, вимірювали поглинання при 750 нм і розраховували загальний фенольний індекс згідно з [7].

Антирадикальну активність екстрактів оцінювали за реакцією зі стабільним вільним радикалом 2,2-дифеніл-1-пікрилгідразилом (DPPH) [8]. За стандартною процедурою DPPH тесту, 1 мл розчину, що досліджується, додають до 2 мл 70 \%-го етанолу та 2 мл 0,15 мМ розчину DPPH у 70 \%-му розчині етанолу. Концентрацію стабільних радикалів у різний час після початку реакції визначають спектрофотометрично за зміною оптичної густини при максимумі поглинання розчину DPPH 520 нм. Як контроль використовують розчин з такою ж концентрацією DPPH, але без екстракту. Оскількі всі досліджені екстракти виявили дуже високу активність у реакції (спостерігали міттєве зникнення забарвлення за умов додавання нерозведених екстрактів до розчину DPPH), перед тестуванням усі екстракти були розведені в 10 разів.

Вплив антиоксидантів на стабільність біодизелю під час зберігання оцінювали за прискореною процедурою [9] за зміною кислотного числа. Бюкси з наважкою 10 г вихідного біодизелю чи з 10 г біодизелю та 0,1 г екстракту поміщали в піч з доступом повітря та витримували при температурі $43{ }^{\circ} \mathrm{C}$ впродовж 4 тижнів; кожен тиждень витримування при температурі $43^{\circ} \mathrm{C}$ відповідає 1 місяцю зберігання палива в звичайних умовах. Раз на тиждень зразки доставали з печі та вимірювали кислотне число біодизелю за процедурою, описаною в [9]. Зразки біодизелю було одержано з олії рижію посівного в Інституті біоорганічної хімії та нафтохімії ім. В.П. Кухаря НАН України [10]. Як антиоксидант використано екстракт, який мав найбільшу антирадикальну активність у реакції з DPРН. Кислотне число визначали титрометричним методом із візуальною індикацією з використанням спиртово-хлороформової суміші за ДСТУ 4350 [11].

На рис. 1 наведено приклади хроматограм рослинних екстрактів. Порівняння хроматограм екстрактів рослин магнолії та камелії показує, що ці види значно відрізняються за вмістом біоактивних сполук різних класів. В екстрактах камелії переважають оксибензойні кислоти і катехіни, тоді як основними компонентами екстрактів магнолій є оксикоричні кислоти і глікозиди кверцетину та кемферолу. Одержані результати щодо вмісту різних фенолів у екстрактах (таблиця) відповідають літературним даним щодо основних біоактивних речовин, присутніх у рослинах $[5,6]$.

У таблиці також наведено загальний фенольний індекс екстрактів рослин, а на рис. 2 дані щодо інгібування екстрактами радикалів DPPH. Згідно з даними рис. 2 і таблиці, усі екстракти виявляють дуже високу антиоксидантну активність, хоча і відрізняються за своїми властивостями. Найвищу активність мають екстракти камелії та екстракт Magnolia kobus, одержаний екстракцією з використанням ультразвуку. Варто відзначити також загальну високу концентрацію антиоксидантів у екстрактах: фенольний індекс 1,5-7,5 (див. таблицю), 


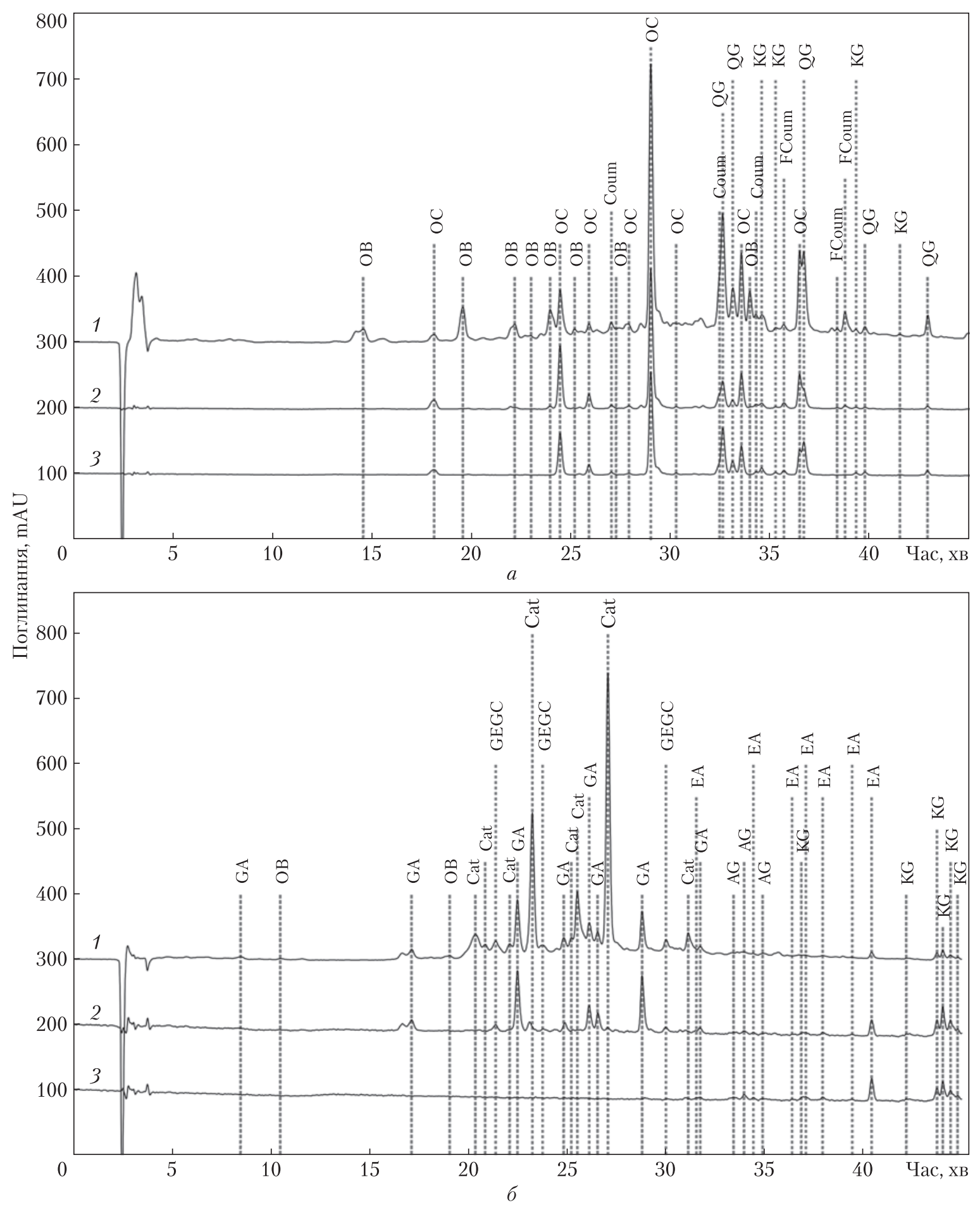

Puc. 1. Фрагменти хроматограм ( 1 -206 нм, $2-300$ нм, 3 - 350 нм) екстрактів Magnolia kobus (a) та Camellia japonica L. (б). Умовні позначення піків: OB - похідні простих фенолів та оксибензойних кислот; OC - похідні оксикоричних кислот; GA - похідні галової кислоти; ЕА - похідні елагової кислоти; Coum - похідні кумарину; FCoum - фуранокумарини; QG - глікозиди кверцетину; KG - глікозиди кемпферолу; AG - глікозиди апігеніну; Сat - катехіни; GEGC - галати епігалокатехіну 
що становить еквівалент 0,7-3,7 мМ розчину такого потужного антиоксиданту, як аскорбінова кислота [12].

Другий висновок, який можна зробити з наведених даних: екстракти, одержані при $60{ }^{\circ} \mathrm{C}$ з використанням ультразвуку, мають кращі антиоксидантні властивості, ніж екстракти, отримані шляхом кип'ятіння. Це спостереження узгоджується з даними аналізу складу екстрактів методом хроматографії (див. таблицю), які показують, що у першому випадку

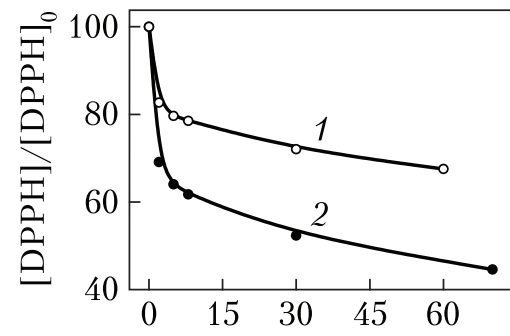

$a$

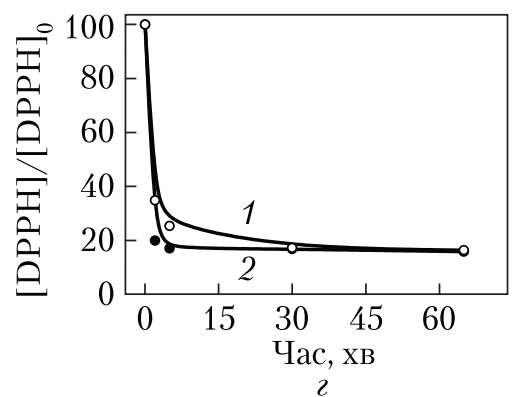

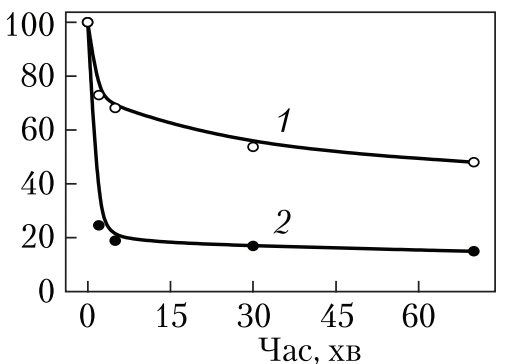

6

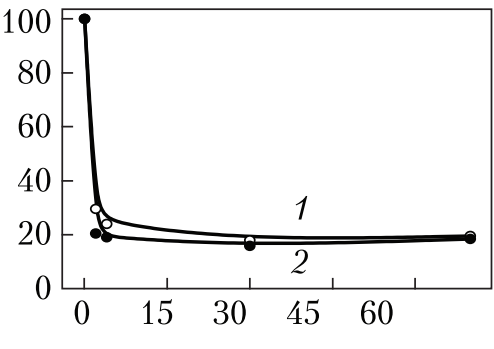

$B$

Puc. 2. Інгібування радикалів DPPH екстрактами Magnolia $\times$ soulangeana Soul.-Bod. (a), Magnolia kobus (6), Camellia japonica L., зразок 1 (в), Camellia japonica L., зразок 2 (2), які одержані шляхом кип’ятіння (криві 1) та нагрівання з використанням ультразвуку (криві 2)

Вміст фенольних сполук (мг/л) і загальний фенольний індекс для екстрактів магнолій та камелій

\begin{tabular}{|c|c|c|c|c|}
\hline $\begin{array}{c}\text { Фенольна } \\
\text { сполука }\end{array}$ & $\begin{array}{c}\text { Magnolia } \times \text { soulangeana } \\
\text { Soul.-Bod., } \\
85^{\circ} \mathrm{C} / 60^{\circ} \mathrm{C}+\mathrm{Y} 3\end{array}$ & $\begin{array}{l}\text { Magnolia kobus, } \\
85^{\circ} \mathrm{C} / 60^{\circ} \mathrm{C}+\mathrm{y} 3\end{array}$ & $\begin{array}{c}\text { Camellia japonica 1, } \\
85^{\circ} \mathrm{C} / 60^{\circ} \mathrm{C}+\mathrm{y3}\end{array}$ & $\begin{array}{l}\text { Camellia japonica } 2 \text {, } \\
85^{\circ} \mathrm{C} / 60^{\circ} \mathrm{C}+\mathrm{y} 3\end{array}$ \\
\hline $\begin{array}{l}\text { Похідні простих фенолів та } \\
\text { оксибензойних кислот }\end{array}$ & $10 / 4$ & $12 / 21$ & $9 / 10$ & $3 / 2$ \\
\hline Похідні оксикоричних кислот & $10 / 26$ & $42 / 95$ & - & - \\
\hline Похідні галової кислоти & - & - & $7 / 4$ & $26 / 32$ \\
\hline Похідні елагової кислоти & - & - & $11 / 18$ & $7 / 4$ \\
\hline Похідні кумарину & $4 / 14$ & $12 / 4$ & - & - \\
\hline Фуранокумарини & - & - & $7 / 7$ & $4 / 7$ \\
\hline Глікозиди кверцетину & $17 / 27$ & $21 / 32$ & - & - \\
\hline Глікозиди кемпферолу & $8 / 12$ & $5 / 4$ & - & - \\
\hline Глікозиди апігеніну & - & - & - & $1 / 1$ \\
\hline Катехіни & - & - & $16 / 11$ & $25 / 37$ \\
\hline Галати епігалокатехіну & - & - & $1 / 1$ & $1 / 2$ \\
\hline Загальна маса фенолів & $49 / 83$ & $92 / 156$ & $51 / 51$ & $67 / 85$ \\
\hline Фенольний індекс & $1,5 / 2,4$ & $2,3 / 7,5$ & $4,1 / 3,8$ & $4,0 / 6,6$ \\
\hline
\end{tabular}




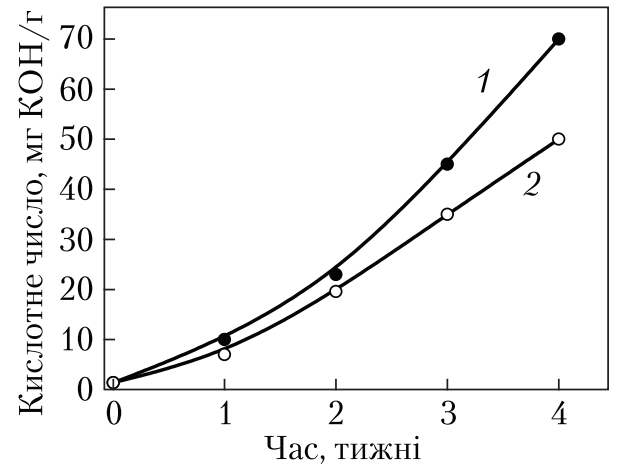

Puc. 3. Зміна кислотного числа в зразках біодизелю без добавок (крива 1) та 3 додаванням екстракту Camellia japonica L. (крива 2) за умов витримування при $43^{\circ} \mathrm{C}$ протягом 4 тижнів

в екстрактах присутня більша кількість активних речовин. Загалом, екстракти, одержані при $60{ }^{\circ} \mathrm{C}$ з використанням ультразвуку, мають і вищі значення фенольного індексу. Більшою мірою це спостереження стосується екстрактів магнолій, для яких співвідношення фенольного індексу в розчинах, отриманих двома різними способами, перевищує 3 (зразок Magnolia kobus).

Більша чутливість властивостей екстрактів магнолій до процедури кип'ятіння може бути пов'язана 3 відмінностями в складі біоактивних речовин, що містяться у рослинах. Як свідчать дані хроматографії (див. таблицю), основними біоактивними сполуками в екстрактах магнолій є глікозиди кверцетину і похідні оксикоричних кислот, тоді як камелії містять переважно катехіни та похідні галової й елагової кислот. Відомо, що кверцетин у розчинах достатньо легко окиснюється з утворенням нових сполук [13]. Катехіни та похідні галової кислоти є більш стійкими під час нагрівання. Згідно з [14], під час нагрівання розчинів катехіну та галової кислоти протягом години при 100 C деградують тільки 15 \% біоактивних сполук.

Ще одна відмінність екстрактів камелії від екстрактів магнолій полягає у тому, що при меншій або близькій загальній масі фенольних сполук екстракти камелії характеризуються більшими значенями фенольного індексу і виявляють більшу активність у реакції з радикалами (див. таблицю, рис. 2); це, вочевидь, також пов’язано з різним складом екстрактів і з різними властивостями біоактивних сполук.

Визначення стабільності біодизелю, навіть за прискореною процедурою, потребує значного часу. Проте навіть попередні дані щодо зміни кислотного числа в зразках біодизелю протягом 4 тижнів (рис. 3) можуть слугувати для оцінки здатності добавок екстракту впливати на окиснення біопалива під час зберігання.

Як можна бачити з даних рис. 3, через 4 тижні спостережень (еквівалент 4 місяців зберігання за стандартних умов) за наявності екстракту кислотне число біодизелю зменшується приблизно на 30 \%. Слід відзначити, що загальна кількість фенолів у доданому екстракті (0,1 г) становить $~ 0,008$ мг, тобто кількість антиоксидантів відносно маси біодизелю дорівнює 1 ррм. Водночас наприклад, у роботі [15] зазначається, що кількість добавок антиоксиданту сягає 1000-2000 ррм. Вочевидь, для підвищення антиоксидантного ефекту потрібно попередньо збільшити концентрацію активних речовин в екстракті, наприклад, шляхом випаровування розчинника. У цьому випадку можна очікувати значного підвищення впливу рослинних екстрактів на стабільність біодизелю.

Таким чином, результати дослідження свідчать про те, що екстракти камелій та магнолій містять велику кількість поліфенолів і мають значні антиоксидантні властивості. В екстрактах магнолій переважають глікозиди кверцетину та похідні оксикоричних кислот, тоді як в екстрактах камелій - катехіни та похідні оксибензойних кислот. Склад екстрактів залежить не тільки від виду рослини, а й від способу екстрагування; загалом, за умов екстра- 
кції з меншою температурою $\left(60^{\circ} \mathrm{C}\right)$ і використанням ультразвуку вдається одержати екстракти з більшим вмістом поліфенолів, ніж у випадку кип'ятіння рослинного матеріалу. Згідно з даними попереднього експерименту, екстракт Camellia japonica L. виявив помітну активність у стабілізації біодизелю; за умов відповідного концентрування, екстракт може бути використаний для істотного підвищення стабільності біодизелю під час зберігання.

Автори висловлюють подяку д-ру хім. наук Л.К. Патриляк та канд. хім. наук С.О. Зубенку, Інститут біоорганічної хімї та нафтохімї ім. В.П. Кухаря НАН України, за надані зразки біодизелю.

Роботу виконано за фінансової підтримки Наџіонального фонду досліджень України (проєкт № 2020.01/0136 “Ефективне використання відновлюваних рослинних ресурсів та фотокаталітична конверсія біомаси як еколого-інновачійні підходи для збереження довкілля та біобезпеки людини”).

\section{ЦИТОВАНА ЛІТЕРАТУРА}

1. Pandey K.B., Rizvi S.I. Plant polyphenols as dietary antioxidants in human health and disease. Oxid. Med. Cell. Longev. 2009. 2, № 5. P. 270-278. https://doi.org/10.4161/oxim.2.5.9498

2. Stavinskaya O., Laguta I., Fesenko T., Krumova M. Effect of temperature on green synthesis of silver nanoparticles using Vitex agnus-castus extract. Chem. J. Mold. 2019. 14, № 2. P. 1857-1727. https://doi. org/10.19261/cjm.2019.636

3. Varatharajan K., Pushparani D.S. Screening of antioxidant additives for biodiesel fuels. Renew. Sustain. Energy Rev. 2018. 82, № 3. P. 2017-2028. https://doi.org/10.1016/j.rser.2017.07.020

4. Лагута И.В., Ставинская О.Н., Дзюба О.И., Иванников Р.В. Анализ антиоксидантных свойств экстрактов растений. Допов. Нащ. акад. наук Укр. 2015. № 5. С. 130-137. https://doi.org/10.15407/ dopovidi2015.05.130

5. Park C.H., Park S.-Y., Lee S.Y., Kim J.K., Park S.U. Analysis of metabolites in white flowers of Magnolia denudata Desr. and violet flowers of Magnolia liliiflora Desr. Molecules. 2018. 23, № 7. P. 1558-1574. https:// doi.org/10.3390/molecules23071558

6. Yoon I.-S., Park D.-H., Kim J.-E., Yoo J.-C., Bae M.-S., Oh D.-S., Shim J.-H., Choi C.-Y., An K.-W., Kim E.-I., Kim G.-Y., Cho S.-S. Identification of the biologically active constituents of Camellia japonica leaf and anti-hyperuricemic effect in vitro and in vivo. Int. J. Mol. Med. 2017. 39, № 6. P. 1613-1620. https://doi. org/10.3892/ijmm.2017.2973

7. Alonso A.M., Domínguez C., Guillén D., Barroso C.G. Determination of antioxidant power of red and white wines by a new electrochemical method and its correlation with polyphenolic content. J. Agric. Food Chem. 2002. 50, № 11. P. 3112-3115. https://doi.org/10.1021/jf0116101

8. Brand-Williams W., Cuvelier M.E., Berset C. Use of a free radical method to evaluate antioxidant activity. LWT. 1995. 28, № 1. P. 25-30. https://doi.org/10.1016/S0023-6438(95)80008-5

9. Westbrook S.R. An evaluation and comparison of test methods to measure the oxidation stability of neat biodiesel. San Antonio, Texas: Southwest Research Institute, 2005. 43 p.

10. Яковлєва А.В., Бойченко С.В., Гудзь А.В., Зубенко С.О. Фізико-хімічні властивості біодизельних палив на основі етилових естерів рижієвої олії. Каталіз та нафтохімія. 2020. № 29. С. 24-31. https://doi. org/10.15407/kataliz2020.29.027

11. ДСТУ 4350:2004 Олії. Методи визначання кислотного числа (ISO 660:1996, NEQ). Київ, 2005. 8 с.

12. Лагута И.В., Ставинская О.Н., Оранская Е.И., Чернявская Т.В. Взаимодействие аскорбиновой кислоты с высокодисперсным кремнеземом. Допов. Нащ. акад. наук Укр. 2009. № 12. С. 152-157.

13. Zenkevich I.G., Eshchenko A.Yu., Makarova S.V., Vitenberg A.G., Dobryakov Y.G., Utsal V.A. Identification of the products of oxidation of quercetin by air oxygen at ambient temperature. Molecules. 2007. 12, № 3. P. 654-672. https://doi.org/10.3390/12030654 
14. Volf I., Ignat I., Neamtu M., Popa V.I. Thermal stability, antioxidant activity, and photo-oxidation of natural polyphenols. Chem. Pap. 2014. 68, № 1. P. 121-129. https://doi.org/10.2478/s11696-013-0417-6

15. McCormick R.L., Westbrook S.R. Storage stability of biodiesel and biodiesel blends. Energy Fuels. 2010. 24, № 1. P. 690-698. https://doi.org/10.1021/ef900878u

Надійшло до редакції 11.02.2021

\section{REFERENCES}

1. Pandey, K. B. \& Rizvi, S. I. (2009). Plant polyphenols as dietary antioxidants in human health and disease. Oxid. Med. Cell. Longev., 2, No. 5, pp. 270-278. https://doi.org/10.4161/oxim.2.5.9498

2. Stavinskaya, O., Laguta, I., Fesenko, T. \& Krumova, M. (2019). Effect of temperature on green synthesis of silver nanoparticles using Vitex agnus-castus extract. Chem. J. Mold., 14, No. 2, pp. 1857-1727. https://doi. org/10.19261/cjm.2019.636

3. Varatharajan, K. \& Pushparani, D. S. (2018). Screening of antioxidant additives for biodiesel fuels. Renew. Sustain. Energy Rev., 82, No. 3, pp. 2017-2028. https://doi.org/10.1016/j.rser.2017.07.020

4. Laguta, I. V., Stavinskaya, O. N., Dzyuba, O. I. \& Ivannikov, R. V. (2015). Analysis of antioxidant properties of plants extracts. Dopov. Nac. akad. nauk. Ukr., No. 5, pp. 130-137 (in Russian). https://doi.org/10.15407/ dopovidi2015.05.130

5. Park, C. H., Park, S.-Y., Lee, S. Y., Kim, J. K. \& Park, S. U. (2018). Analysis of metabolites in white flowers of Magnolia denudata Desr. and violet flowers of Magnolia liliiflora Desr. Molecules, 23, No. 7, pp. 1558-1574. https://doi.org/10.3390/molecules23071558

6. Yoon, I.-S., Park, D.-H., Kim, J.-E., Yoo, J.-C., Bae, M.-S., Oh, D.-S., Shim, J.-H., Choi, C.-Y., An, K.-W., Kim, E.-I., Kim, G.-Y. \& Cho, S.-S. (2017). Identification of the biologically active constituents of Camelliajaponica leaf and anti-hyperuricemic effect in vitro and in vivo. Int. J. Mol. Med., 39, No. 6, pp. 1613-1620. https://doi. org/10.3892/ijmm.2017.2973

7. Alonso, A. M., Domínguez, C., Guillén, D. \& Barroso, C.G. (2002). Determination of antioxidant power of red and white wines by a new electrochemical method and its correlation with polyphenolic content. J. Agric. Food Chem., 50, No. 11, pp. 3112-3115. https://doi.org/10.1021/jf0116101

8. Brand-Williams, W., Cuvelier, M.E. \& Berset, C. (1995). Use of a free radical method to evaluate antioxidant activity. LWT, 28, No. 1, pp. 25-30. https://doi.org/10.1016/S0023-6438(95)80008-5

9. Westbrook, S. R. (2005). An evaluation and comparison of test methods to measure the oxidation stability of neat biodiesel. San Antonio, Texas: Southwest Research Institute.

10. Yakovlieva, A. V., Boichenko, S. V., Hudz, A. V. \& Zubenko, S. O. (2020). Physical-chemical properties of biodiesel fuels based on camelina oil ethyl esters. Catalysis and petrochemistry, No. 29, pp. 24-31 (in Ukrainian). https://doi.org/10.15407/kataliz2020.29.027

11. DSTU 4350:2004 Oils. Methods for determining the acid number (ISO 660:1996, NEQ). Kyiv, 2005.

12. Laguta, I.V., Stavinskaya, O.N., Oranskaya, E.I. \& Chernyavskaya, T.V. (2009). Interaction of ascorbic acid with highly dispersed silica. Dopov. Nac. akad. nauk Ukr., No. 12, pp. 152-157 (in Russian).

13. Zenkevich, I.G., Eshchenko, A.Yu., Makarova, S.V., Vitenberg, A.G., Dobryakov, Y.G. \& Utsal, V.A. (2007). Identification of the products of oxidation of quercetin by air oxygen at ambient temperature. Molecules, 12, No. 3, pp. 654-672. https://doi.org/10.3390/12030654

14. Volf, I., Ignat, I., Neamtu, M. \& Popa, V.I. (2014). Thermal stability, antioxidant activity, and photo-oxidation of natural polyphenols. Chem. Pap., 68, No. 1, pp. 121-129. https://doi.org/10.2478/s11696-013-0417-6

15. McCormick, R.L. \& Westbrook, S.R. (2010). Storage stability of biodiesel and biodiesel blends. Energy Fuels, 24, No. 1, pp. 690-698. https://doi.org/10.1021/ef900878u

Received 11.02.2021 
I.V. Laguta ${ }^{1}$, O.N. Stavinskaya ${ }^{1}$, P.O. Kuzema ${ }^{1}$, R.V. Ivannikov ${ }^{2}$, V.N. Anishchenko ${ }^{3}$, O.P. Linnik ${ }^{1}$

${ }^{1}$ Chuiko Institute of Surface Chemistry of the NAS of Ukraine, Kyiv

${ }^{2}$ M.M. Gryshko National Botanic Garden of the NAS of Ukraine, Kyiv

${ }^{3}$ L.M. Litvinenko Institute of Physical-Organic Chemistry and Coal Chemistry of the NAS of Ukraine, Kyiv E-mail: icvmtt34@gmail.com

\section{ANTIOXIDANT PROPERTIES OF PLANT EXTRACTS FOR BIODIESEL STABILIZATION}

Using two different extraction procedures, eight ethanol plants extracts are obtained from the leaves of Magnolia $\times$ soulangeana Soul.-Bod., Magnolia kobus, and two samples of Camellia japonica L. The composition and antioxidant properties of the extracts are studied by means of high performance liquid chromatography, the FolinCiocalteu method, and DPPH test. Hydroxycinnamic acids and quercetin glicosides are found to be the main constituents of Magnolia extracts, while hydroxybenzoic acids and catechin derivatives prevailed in Camelia extracts. The composition of the extracts was also affected by extraction procedures; in general, the extracts obtained at $60^{\circ} \mathrm{C}$ under ultrasonic treatment contained phenolic compounds of a higher quantity than the extracts prepared by boiling the leaves in $70 \%$ ethanol at $\sim 85^{\circ} \mathrm{C}$; the overall amount of phenolic compounds in the extracts was in a range of 50-150 mg/l. In spite of significant distinctions in the content of phenols, all the extracts were found to possess a very high antioxidant activity in both Folin-Ciocalteu and DPPH assays. The extracts were found to have the total phenolic index of 1.5-7.5. During $30 \mathrm{~min}$ of the reaction, seven of eight extracts inhibited more than $50 \%$ of DPPH radicals under standard test conditions, even being diluted by 10 times. The extract of Camellia japonica L. with the highest antioxidant ability was also tested as an additive to stabilize the biodiesel against oxidation. The stability of biodiesel prepared from Camelina sativa (L.) Crantz was studied according to accelerated procedure at $43^{\circ} \mathrm{C}$ for four weeks, with the changes in the acid value of the samples being the criteria of fuel oxidation. The preliminary results showed that Camellia extract may be a promising stabilizing additive to reduce the biodiesel oxidation.

Keywords: plant extracts, phenolic compounds, antioxidant properties, biodiesel stability. 